\title{
VARIOUS WORKS IN THE PERGAMENE STYLE.
}

TuE chief object of this paper is to record and classify the various monuments which on the ground of subject-matter or style may claim to be connected with Pergamene work. It may be well also to notice by way of introduction what we can gather from ancient testimony.

Of most of the existing works that I shall mention I have had personal knowledge, and where I have had to rely merely on published representations of them, I can only bring them forward for the purpose of suggesting to those who have direct acquaintance with them to consider them from this point of view. The theory which I wish to work out-a theory already suggested by others-is that certain fields of Greco-Roman and late Roman art have received a deep and abiding impress from Pergamon. That this should be a priori probable does not need elaborate proof; Rome was the heir of the Pergamene kingdom, and had always friendly intimacy with it, and we hear of many Pergamene works being transferred to Rome by Nero (Dio Chrys. $644 R$.) : between certain Roman and certain Pergamene myths there was a close analogy, which coloured the artistic representation of them: the struggle of the Pergamene kingdom with the Gauls, or-to speak perhaps more correctly-with Antiochus Hierax supported by Gallic mercenaries, ${ }^{2}$ was the most recent counterpart to the struggle of Rome with the barbarians: it was the Pergamene school-as Professor Brunn was the first to demonstrate -who idealized and fixed for artistic representation the type of the northern barbarian and really created historic sculpture, ${ }^{3}$ and I think that it can be shown that their rendering of this type became conventionalized and remained traditional throughout many centuries.

But the preliminary question which it is essential to answer is whether it is allowable to speak of a Pergamene style at all. For unless works done at Pergamon or in connection with Pergamon showed certain specific points of resemblance between themselves and a certain distinctiveness, we might

1 E.g. the exposure of the twins and Telephos, the infants suckled by the wolf: compare the legend in Plutarch (Romulus ch. 2) that Aeneas married Roma, a daughter of Telephos.

2 Vide Köhler, Die Gründung des Königsreichs Pergamon : Urlichs, who combats many of his arguments in his Pergamenische Inschriften, yet admits the main part of his theory.
3 Isolated works, such as the Nubian heada bronze work from Cyrene-published by Rayet, Mon. de l'art Antique 2. No. 58, showing powerful realistic treatment of the barbaric type, are perhaps earlier than the Pergamene school: but theirs is the earliest systematic work in this field which could make a new epoch in sculpture. 
affiliate Greco-Roman art in general to Hellenistic art in general, but no part at all of the former to Pergamene art as a species of the latter.

Is there then a Pergamene school whose work may be regarded as a species in this sense?

Urlichs ${ }^{1}$ implicitly negatives the supposition, simply because the inscriptions prove that artists of many different nationalities worked at Pergamon, Athenian, Sicyonian, Boeotian and Rhodian sculptors having combined to embellish the Attalid capital; but when he wrote he had not seen the fragments at Berlin. This on the whole appears to be also Dr. Conze's view, ${ }^{2}$ who speaks of Pergamene art as a sort of $\delta \iota a \lambda \epsilon \kappa \tau o ̀ s \kappa o \iota \nu \eta^{\prime}$, an eclectic art, gathering together the various characteristics of the older schools. And this is partly true, but not the whole truth.

In spite of all this eclecticism, the works that are known to have come from Pergamon and its vicinity display on the whole certain common qualities and features which have not appeared at all or not in equal degree of development in earlier works. These qualities one may either praise or blame, but it is not the object of this paper to dwell on questions that concern the philosophy of art. I have tried to express in former papers in this Journal some of the common and essential characteristics of this sculpture, and I will try briefly to record these here, chiefly so far as concerns the rendering of the forms. But one ought first to notice the question from which of the two periods of the Pergamene work are these to be gathered, from the older period of Attalus I. or the younger of Eumenes II. Professor Brumn finds in the Neapolitan statuettes, which have descended to us from the Attalid dedication at Athens, traces of the workmanship of the earlier and more creative generation. On the other hand Dr. Conze maintains that the starting-point of our criticism must always be the chef d'œuvre of the younger generation, the Pergamene altar; and the reasons are strong for adopting his view. The objects that in the last few years have been drawn from the soil of Pergamon are originals of first-hand value, uncorrupted by the hand of the renovator : the Neapolitan works are very poor copies, almost characterless, and only by a very probable hypothesis can be connected with the Attalid originals; and in any case through this comparative lack of character they fail to give us a standard for measuring the later effect and influence of this local style. ${ }^{3}$

1 Pergamenische Inschriften, p. 27.

2 Göttingen Gelehrte Anzeigen, 1882.

$3 \dot{M}$. Reinach in the Bulletin de Corr. Hellén. (Janv. 1889) and Dr. Milchhöfer in Die Befreintng des Prometheus give a more favourable estimate of the Neapolitan works, both maintaining that they cannot be copies of the Greco-Roman age. They may certainly be copies wrought in Asia Minor, but after a careful study I failed to detect in them any excellence of style or execution that might prevent us assigning them to the Greco-Roman period. The prostrate giant suggests a good original, but the work is dull and cold. Neither in face nor attitude is there much power of expression, and the treatment of the muscles, the hair, and the wild-beast's fell, shows little marked style or 'Pergamenian' character.

Still more superficial and dull is the rendering of the Amazon; though the drapery shows some skill and delicacy. The face has the high oval contour common in Alexandrine sculpture, but none of the specific marks of that type which appears on the frieze. The figure of the 
The chief forms of what may be called the Pergamene countenance are as follows. The contour is a rather high oval, the height being proportionately greater than the breadth; the emphasis is laid on the flesh rather than on the bone-structure; the forehead is rather high and marked with. a strong protuberance of flesh, the space between the eyes is great and the depth of the eye-sockets is strikingly great; the over-hanging eyebrows are realistically rendered and are often drawn up in the middle of their curve; the flesh at the outer corner of the eyes frequently is swollen, and the centre of the eyeball itself often protrudes. The lips are full and short and half-parted, and the upper one is usually arched and the centre of it pouts forward. The throat appears as a columnar support of the head, the under surface of the cheek springing as it were from the throat in low relief. The hair is rendered in a wild and confused mass.

The prevailing expression of the face-which these forms evidently assist -is one of physical pathos ${ }^{1}$ or sensuons vehemence, a wild and undisciplined expression, barbaric or gigantesque.

The principle that governs the treatment of the head appears also in the rendering of the torso and the limbs: the effect desired and attained is that of temporary rather than permanent life and form. The bone-structure cannot of course be altogether concealed, but the eye is rather arrested by the swelling courses of flesh which are massed together to produce the barbaric or gigantic type. And both in the Pergamene face and torso there is a manner of handling the forms by which they appear liquid or fluent: that is, they seem to lack fixedness and to melt away one into another. Another way in which this interest in the momentary life and in the superficial aspect of the body is manifested is the naturalistic representation of such details as the hair on the breast and in the arm-pits, the drops of blood flowing from a wound, the wrinkles of the skin, the swollen veins. And the same love of mere detail is shown in the exact expression of the different textures of drapery.

Lastly, as regards the composition, we detect in the larger frieze and still more clearly in the smaller the tendency to crowd the figures together and to overload the action, whereby risk is incurred of losing plastic distinctness.

It might be supposed that the formal and spiritual qualities of this

dying Persian displays more obviously still the cold formalism of the later copyist's hand : there is a moderate expression of pain in the face, and some violence in the attitude, but otherwise little that speaks of any school. The dying Gaul of Naples has far more character and gives some proof of the Pergamene power in historic sculpture; but if the earlier GrecoRoman period could not produce such imitative works as these, it had fallen very low. The 'Attalid' figures at Venice are of far higher value, but even these we can best estimate after considering the data afforded by the monuments from the soil of Pergamon.

1 Perhaps by such a term we may distinguish 'Pergamenian' expression from the expression in a work of Scopas, a mental or spiritual pathos -such for instance as the epigrammatist found in the unknown $\zeta_{\gamma \alpha \lambda \mu \alpha}$ M $\eta \delta \in$ ias (Anthology, ix. 593).

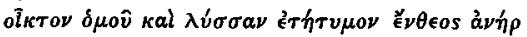

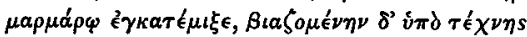

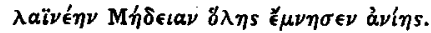


sculpture as thus summarized are only found in the representation of the giants on the frieze, and are reserved for this theme or for the barbaric type, to which they are appropriate. If this were true, it would still be desirable to see if this style appeared in the Greco-Roman work that dealt with the same subject. But it is interesting to note that this reservation was not made by those who worked at Pergamon: that, though it is the giant-head of the youthful type that is the completest example of what I have called the Pergamene countenance, yet some of the essential traces appear in the faces of the divinities, and also in the human faces of the smaller frieze : nor is it only in the giant-body that the violent treatment of the muscles is seen. It has been made a complaint about the figure of Zeus in the frieze that the torso is too gigantesque. Also the excited and over-vehement expression is given to the faces not only of the giants but of some of the divinities as well. In spite of the fact therefore that many of the best traditions of the older sculpture were maintained at Pergamon, we have here a peculiar type of forms and a mode of expression becoming fixed and conventional.

Again, the qualities of this style appear throughout the whole of this colossal frieze in greater or lesser degree of impressiveness. The sculptors are from many nations, but there is unity in their work ; and though of course there are great differences of skill in the execution of different slabs, yet no one has yet succeeded in assigning this series to the Attic and that to the Rhodian workshop. For instance, the figure which for no particular reason has been called Orion shows-as I have before pointed out-a drier and more restrained style than most of the others, and a more prominent marking of the bone-structure of the head. But we cannot claim this slab for the austerer style, independent of Asiatic voluptuousness; for in the face and form of the giant that lies at his feet the marks of the 'Pergamene' style are most conspicuous. Many special points of difference might be discovered between the series of slabs on which Hekate and the kindred divinities are represented, and that on which Amphitrite and the sea-divinities appear in combat. Not only is the execution inferior in the latter, but there are fewer specific marks of the school in the rendering of the torso and the face. But there is no new principle of composition, no different theory of formal treatment in this group, so that we might speak of a separate and independent style.

And-as I have incidentally noticed before and will soon show by illustration-the heads of the smaller frieze show on the whole the same characteristics as those on the larger, only that the dominant expression is less intense and their contour is rounder and softer, and the marking of the bone-structure of the skull which may be discerned on two heads of the larger frieze cannot be discovered on this.

The result of this brief and general statement will be this-that as a certain spirit and style appear throughout the mass of sculpture discovered on the site of Pergamon, and as no earlier work of sculpture displays the same style so conspicuously or so consistently, and as this has become a mannerism at Pergamon being used irrespective of theme, it is natural and scientific to 
speak of a Pergamene style or epoch : and the Pergamene is a species of the Hellenistic work.

We may admit that there was no Pergamene 'school'-that is a body of native sculptors showing in their work the impress of local character and influence. But those who worked at this place worked de consilii sententia, with some unity of method and theory, and what they achieved was important enough to serve as a standard.

To trace the prior influences that explain this style and to collect the elements in the older sculpture from which it is built up, lies beyond the scope of this paper. But in passing I may illustrate the theory that I advanced before of an affinity between the style of Scopas and Pergamene work. Certain striking traits in the Pergamene type of countenance appear in the Tegean heads from the temple of Athene Alea: these are the protuberance over the forehead, the great breadth between the eyes, the very deep eye-sockets, and the protruding centre of the eyeball. I was strongly impressed with the resemblance between the head of the giant who is attacked by the goddess with the mysterious jar and the youthful helmed head from Tegea; and one of the larger heads from Pergamon in the magazine of the Berlin Museum shows the same expression of mouth and the same roundness of forms as some of the separate female heads in the British Museum found at the Mausoleum. That Scopas' style had great vogue in Asia Minor is in accord with the account of his life and sphere of work. ${ }^{1}$

Before enumerating those monuments for which there is only internal evidence of connection with the Pergamene school, I will briefly record those of which the 'provenance' from Pergamon is certain, and which are of value in illustrating the special style.

Besides the great frieze, there are the slabs of the smaller frieze which probably ran round the interior of the altar, most of which are still in the magazine of the Berlin Museum. The subject-matter of these has been successfully and skilfully explained by Professor C. Robert in the numbers of the years 1887 and 1888 of the Jahrbuch des Archäologischen Instituts, but without much reference to the details of the style. I am only concerned here with shortly illustrating the affinity which I have already affirmed to exist between the sculpture of the smaller and that of the greater frieze.

In the representation of Telephos with the infant Orestes and the young Electra, ${ }^{2}$ the face of Electra shows some of the marks of the type described, and the torso of Telephos the characteristic handling.

The group of Heracles and the infant Telephos ${ }^{3}$ suckled by the wolf is very interesting on account of the connection which it has with representations which will be noticed later of the Greco-Roman period. It concerns the present point because the forms display the Pergamene style

\footnotetext{
1 On a Bithynian coin of Lysimachus (in the British Museum, soon to be published in the series of Bithynian Kings) is a head of Heracles with many of the essential traits of the Pergamene type of countenance.
}

${ }^{2}$ Sketched in Die Ergebnisse der Ausgrabungen zu Pergamon, p. 66.

3 Overbeck, Geschichte d. Griech. Plastik, vol. ii. fig. $133 a$. 
very markedly. The rendering of the abdomen and of the swelling courses of muscles above the hip recall the sculpture of the gigantomachy; the pose of the arm across the breast, by which the biceps and pectinal muscles are joined, is probably chosen partly because this sculpture is fond of dealing with colossal masses of flesh. Though the motive is very different, the pose is the same in the representation of the giant who is sinking down beneath Zeus. In the battle-piece, the scene sketched in Professor Robert's paper, ${ }^{1}$ we are in various ways reminded of the larger frieze; the dead man falling head-downwards is a familiar motive; there is the same profuse detail of slaughter here as there-the same realistic rendering of the blood rushing from the wound, and the structure of the forehead and the eyes and the rendering of the hair are the same. Another scene of combat, ${ }^{2}$ in which a naked warrior is falling with blood dripping from his side, and the helmed head of another is seen prostrate on the ground beneath, produces a very similar effect as the last.

On three unconnected slabs of the smaller frieze we notice strikingly similar types of heads: namely, on one where a bride is standing before the statue of Athene Polias ${ }^{3}$ and a bearded man is by her side; another ${ }^{4}$ where a kingly figure with his guards is hurrying along as though at some sudden news; a third ${ }^{5}$ where another bearded man is raising a laurel-bough towards a statue of Apollo. In all three the male countenance has most of the same forms and the same peculiar expression as we find in so many heads of the larger frieze-the deep-set eyes and the great breadth between them, the protruding forehead, the fleshy cheek-bones, and that expression restless and unfixed which is difficult to describe. Now, according to Robert's most probable explanations, the personality is different in each case, and we cannot say that in each case it is the head of Telephos who appears in three different scenes. In fact we are here presented with a fixed form, which the Pergamene sculptor uses without much consideration of personality or ethos. It appears again in a free head which is exhibited in the Museum near to one of these slabs, and which is supposed to be a head of Poseidon.

The last point of resemblance between the larger and the smaller frieze which need be noticed here is the careful exactness with which both in one and in the other such accessories are rendered as the texture of the drapery, the feathers of the helmet's plumes.

It may then be concluded that the smaller monument, though carved perhaps by different hands, belongs immediately to the same school of work.

On the other hand, it is markedly distinguished, as Overbeck has well pointed out, by the picturesqueness of its relief style. The picturesque element had not indeed been wanting in the frieze-work of the gigantomachy; but the handling of the surface of the relief was there entirely in accord with the old plastic tradition: the background is the same for all the figures, and

\footnotetext{
1 Jahrbuch des Arch. Inst. 1887, p. 256.

${ }^{2}$ Robert, Jahrb. d. Arch. Inst. 1888, p. 91, T.

3 Jahrbuch des Arch. Inst. 1888, p. 45, Pl. I.

4 Ibid. p. $87, \mathrm{Q}$.

5 Ibid. p. 57, P.
} 
all are on the same plane. But in the Telephos slabs there is often an ideal background, perhaps a natural scene, and figures are on a higher and lower scale, and the groups are massed together in different layers. This arrangement, as well as the plastic framework by which the scenes are divided, betrays the influence of painting on sculpture-an influence beginning to be dominant in the Alexandrine period-and probably gives us the clue for explaining the picturesque character of Roman relief work. If this theory be true, a general method of composition will have been borrowed for Rome from Pergamon.

Besides the Telephos frieze, there are many other fragments of sculpture brought from Pergamon, most of them lying at present in the magazine of the Berlin Museum. But it is not possible to find much of the local characteristic style in all of them, and it would be unreasonable to expect such uniformity; for Pergamon was a storehouse of works of art gathered from all parts of Greece, and the first Attalus took his share of the spoils of Corinth. Thus such works as the Athena Nike, the helmed head and headless statue of Pallas in the Pheidian style, ${ }^{1}$ and many of the larger mutilated figures not yet exhibited may have no real connection with the site on which they were found, and do not weaken the theory derived from other works of a specific Pergamene style.

To those of this latter class that have already been examined may be added the following:-

(a) The remains of a seated male figure, lacking the head and arms, the left leg and most of the right: on his back was a mantle, a fold of which appears on his right thigh, and on his neck are traces of long hair. The right arm was brought across the breast, as if it were resting on some support at this side, and the whole body is inclined in this direction. The most conspicuous mark of its style is the very soft treatment of the surface and of the large fleshy masses; the breasts are very swollen and almost feminine, and this fact, together with the pose and the whole rendering, suggests a statue of Dionysos. If this is the right name, we have then four representations of the god from the site of Pergamon-this seated figure, the slabs from the larger and a smaller frieze found on the same site representing

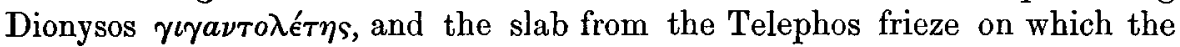
god has been discovered moving hastily to the left, the three last having very much in common with each other and with the local style. Now we know that there was a worship and a temple of Dionysos at Pergamon, and we can gather its importance from more than one source. ${ }^{2}$ It is not improbable that among the mentioned fragments of sculpture survives a reproduction of the temple statue, which may more naturally be supposed to be that of a seated or peaceful figure; but other examples may be quoted of a temple divinity represented in active or dramatic pose, and it is not impossible that the figure on the reliefs preserves something of the forms of the temple statue.

1 Vide Hellenic Journal, 1886, p. 271, 'The Works of Pergamon and their Influence.'

${ }^{2}$ Vide the oracle in C.I.G. 3538 : Dio Cassius,
Book XLI. 61 : letter from Ptolemy to the Pergamenians, C.I.G. 3537 . 
Unfortunately, the coinage of Pergamon does not supply us with any clue; but a coin of the Cilician Seleucia shows us the figure of Dionysos closely resembling that on the Pergamene frieze-slabs. ${ }^{1}$

(b) The cast of a large statue of Hermaphrodite, placed in the Assyrian room, the original of which was found about the south-east of the altar, and is now at Constantinople. The right arm is missing, and the left shoulder has been restored with plaster. At present the work has attracted notice only on the ground of an obvious resemblance in the arrangement of its drapery to the Venus of Milo-a resemblance which may be only accidental, and which contributes nothing to the solution of any question concerning the latter; but it deserves serious attention on other grounds, and chiefly because it is the only Greek statue which has survived of this semi-oriental figure. The Hermaphrodite of the Louvre and that of Florence are only Greco-Roman copies, and still later and inferior to these in execution is the St. Petersburg statue. The Pergamene work far excels these in execution, for the surface is softly and warmly wrought, and in moral conception, for the combination of male and female forms is given without any particularly sensual effect. The face is high, and springs in low relief from the throat; the flesh is strongly emphasized, but the cheek-bones are also marked. The features are close, so to speak, and rather flattened, the chin being short and drawn up as it were to the mouth; the lips are full and rather pouting. There is nothing original in the pose, as the body inclines rather languidly towards the left, the left arm resting on the trunk of a tree. The only other work of the same subject that it recalls in the disposition of the drapery and partly in its attitude is the Hermaphrodite of the Villa Pamphili.2

It would be interesting to know if there was any affinity between the statue from Pergamon and the 'uobilis Hermaphroditus' of Polycles. The question is of course fore-judged if we assume that the copies of the sleeping Hermaphrodite, the statues in the Louvre and Florence and St. Petersburg, preserve the type and form of the original which Pliny praises; but this is only an archaeological conjecture. At any rate, the Polycles whose work upon this theme was most notable cannot have been the sculptor of Ol. CII., but either the second Polycles of the middle of the third century or the latest of this name belonging to the Attic 'revival.' 3 And it is not improbable, from the internal evidence of Pliny's text, that it is the sculptor of this latest period to whom he refers. ${ }^{4}$ In this case the Hermaphrodite of Polycles might be almost contemporary in origin with that which has been brought from Pergamon, and which will always remain of importance for a certain simplicity and freshness it possesses, and its comparative purity of expression and form.

(c) A statue of a tall male figure, standing at ease, his weight being

1 Mionnet, vol. iii. p. 601 : Cilicia, No. 298.

2 Clara.c. Pl. 667 , No. 1548 , A.

3 Vide C. Robert, Hermcs, xix. p. 307.

4 In the first part of sec. 19, Book XXXIV., Pliny enumerates the various epochs of bronze- seulpture, and afterwards the works that illustrate these epochs. If the Polycles he mentions is not the latest sculptor of that name, then he has left the latest period without any monument to illusirate it. 
thrown on his left leg, and his left hand gathering up his garment, which leaves bare his breast and right shoulder; most of his right arm is missing, but it seems to have been lifted and supported perhaps on a staff. The face is rather full and covered with a short beard; the hair is somewhat raised above the forehead, which is prominently marked and barred. Although the expression of the face is not very definite, the statue is very probably an Asclepios; for the position of the arms, the arrangement of the drapery and the treatment of the hair accord with a representation of the god that appears on certain Pergamene coins. ${ }^{1}$ If the figure is really an Asclepios, it is then the earliest instance yet discovered among Pergamene monuments of a type of the god of which the origin is doubtful, and which is probably quite distinct from the well-known work of Phyromachus.

(d) Somewhat different in form from the last is a small figure in terracotta exhibited in the Antiquarium at Berlin, an undoubted Asclepios and of Pergamene 'provenance.' The god is once more erect, and the himation covers the lower part of the body and the left shoulder in the same fashion, but his right hand is resting on his hip, and in his left is the serpent-rod. In these respects it is a replica of the statue from Cyrene published in the Hellenic Journal (IV., p. 47); but the terra-cotta figure is bearded, and a youthful Asclepios is a type that has not yet been found at Pergamon, although we might believe that it was not unfamiliar to the native imagination, since in the vision of Aristides the god wore some of the forms of Apollo. ${ }^{2}$

(e) The two satyrs from Pergamon, published by Dr. Furtwängler, ${ }^{3}$ the one a perfectly preserved bronze figure, the other a statue of Parian marble wanting the head and arms. The meaning and probable genealogy of these works have been fully discussed by the above-mentioned writer; it is only necessary to note here that the rendering of the anatomy shows in each case the manner pectiliar to the school, namely, the powerful articulation of the flesh, and that the execution of the panther's fell and of the nebris reminds us of the skill so notable on the frieze in the handling of different materials. Whether the bronze figure with its plebeian and bucolic type of head supplies us with another criterion for bringing certain works-hitherto isolated-under the Pergamene species, may be afterwards considered. It may appear thas this type is not especially Pergamene. But the figures prove at least that we may attribute to this school an affection for strained and complicated movement and pose--'a rhythm distortum et elaboratum'that descends to them from Myron.

( $f$ ) The torso and lower body of a Triton, one of the figures that stood on the acroterion of the altar. I have already mentioned that most of these appear to be free reproductions of the divinities of the larger frieze, and their movements suggest the same action. It is quite possible that this statue of the Triton has the same dramatic meaning, for his right arm was evidently

1 Vide Warwick Wroth, 'Asclepios on the Coins of Pergamon,' Num. Chron. Ser. III. vol. ii. p. 22, P1. II. 8 .

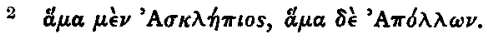
Aristid. Iep. $\lambda \circ \gamma$. B., Dindorf, i. 469.

3 Vierzigstes Programm zum Winckelnaannsfeste 1880 . 
raised on high as though brandishing a weapon, and his left hand holds a shell. There may be an allusion here to the old tradition according to which Triton served as trumpeter in the gigantomachy. The torso is treated so as to suggest the liquid element to which the personage belongs, and that the Pergamene sculpture achieved something in the representation of the beings of the sea the Triton of the Vatican-to be considered later-gives us fair reason to believe. It is evident that the skill which this sculpture possesses in softly rendering the surfaces of the flesh would stand it in stead when handling this theme.

(g) The female head well known through photographs and casts, which might be more conveniently considered in connection with the "Venus of Milo.'

(h) I have referred above to fragments of a smaller relief-work, containing figures about fourteen inches in height, which has been brought to Berlin from Pergamon, and which is of some interest because it also represents a gigantomachy and copies certain groups of the larger altar. For instance, we see the figure of Dionysos showing the same treatment, the same half-feminine forms, and the same posture as the Dionysos of the larger frieze; the face is well preserved, and of the same type as the other heads of Dionysos which I have examined. Of much ruder work are two other reliefs, perhaps belonging to a consecutive frieze, but probably of later origin than that just mentioned, representing Zeus and Athene in the battle. The god is striding forward with violent action, with his left foot on a prostrate giant of human form; brandishing the thunderbolt in his right hand, with his left he has caught a serpent-footed giant by the hair (though the hand is missing, the interpretation is hardly doubtful). Zeus bears no aegis, and the resemblance of the scene to the greater frieze is not very close. The rendering of the forms shows the later exaggeration of the Pergamene style, and there is no fineness of surface. Athene with the aegis is hurrying to the left; only the right half of her body and no part of the neck and shoulders is preserved. The figure somewhat resembles the bronze of Athene with the giant published in the Hellenic Journal, Vol. IV., p. 91.

(i) Of much greater importance is a free statie of Zeus about six feet in height, which I have slightly referred to in a former paper-one of that series of statues which were probably carved simultaneously with the frieze-work of the great altar, and which probably stood above it between the pillars of

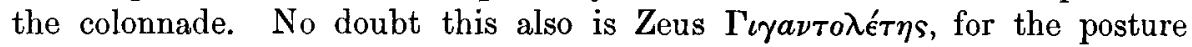
and drapery are very similar to those of the Zeus on the frieze. And the differences arise mostly from the inevitable differences between a relief-figure in a group and a single free statue; that is, the action is less dramatic and violent. The head of this Zeus is only slightly inclined to the right, and the action is more directly to his front; there is no back-swing of the body, but he is striding forwards with right foot advanced and right arm uplifted. There is a certain dignity also and reserve in the motive of the left arm which merely supports the drapery, and the muscles are not so violently rendered nor the veins so swollen. If this is copied from the frieze-figure- 
of which I am doubtful - it is a very intelligent copy, and takes an important place in our scanty series of Zeus-statues of a Greek period (Fig. 1).

Besides these works of sculpture there are several moulds, found on the site of Pergamon, for statuettes and reliefs, which are exhibited in the Berlin Antiquarium. Many of them are for the forms of divinities, such as Hermes, Apollo, Bacchus, Aphrodite, but it is hard to discern in them any features

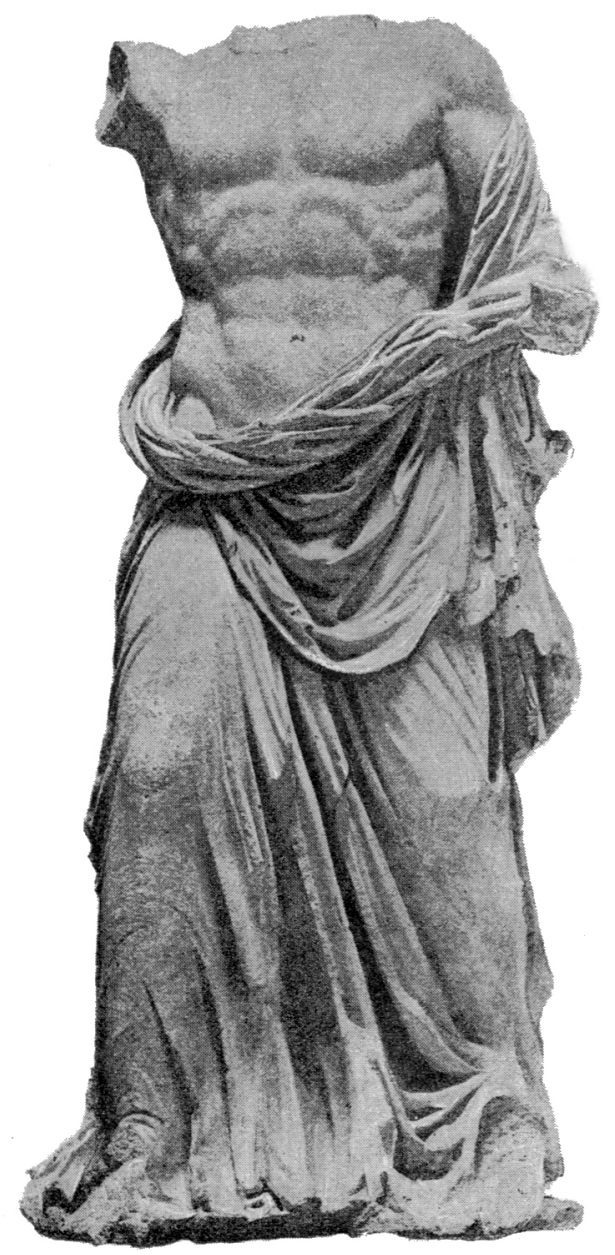

Fig. 1.

specially characteristic of Pergamene work except in the Hermes, whose forehead and chest recalls something of the style.

There are also in the Antiquarium a number of small terra-cottas from Pergamon, but few of them give any clear illustration of the native manner, and the aggregate of them do not serve to corroborate Pliny's ${ }^{1}$ remark con-

' N.H. 35, 160: 'In Asia Pergamon retinet nobilitatem hujus artis.' 
cerning the fame of Pergamene pottery. Two of them deserve mention here: one a female head (No. 6702), showing the unmistakable marks of the type; another a torso, that might be that of Eros or Bacchus, in many ways resembling the fragmentary statue described above, especially in the soft handling of the large masses of flesh on the breast and abdomen. And here also a chlamys is seen, passing round the left shoulder and appearing on the right hip.

So far as I am aware no museum, except the Berlin and the British, the University Galleries at Oxford, and the museum at Constantinople, possesses any monument of marble, bronze, or terra-cotta that is known to have come from the site or immediate vicinity of Pergamon. And all that we have is the colossal torso from Elaea-the port of Pergamon-which has not yet been published. It is probably a fragment of a statue of the seated Heracles. The characteristic style is very noticeable in the soft and lax rendering of the forms, and the deep depressions that throw strong shadows over the large masses of flesh, in the treatment of the lower part of the torso, and in the swollen veins.

The only other marble work that may with certainty be added to this list is a male head from the smaller frieze, in private possession at Dresden, of which I have no personal knowledge, but which is briefly mentioned in the Archäologische Zeitung of 1884 (p. 63).

The coinage of Pergamon contributes much to our knowledge of the local cults, and occasionally illustrates a local myth, but exhibits very little of the peculiar style in question. Nor should we expect to find much of it on this class of monuments ; but an Alexander's head in the lion's skin on a coin probably of the period of Eumenes II., ${ }^{1}$ and a Pergamene coin of the time of Septimius Severus, showing Heracles with the hind of Cerynea, recall the familiar style in the rendering of the forehead and eyes.

A few fragments-not long discovered and not yet published, so far as I am aware-from the Stoa of Attalus II. at Athens may perhaps be reckoned among the monuments that come from the site or territory of Pergamon. Whether the king employed his own sculptors or Athenians for the decoration of his monument might be an open question; but the style of these fragments makes for the former supposition.

(a) A female head inclined to one side, with a veil falling over the back part. It has the peculiar highly-wrought expression which the sculptors of this school loved to give; and it shows their characteristic treatment of formsthe long oval contour, the deep eye-sockets, the forehead protruding in the centre, the short firm mouth. We might name it a head of Demeter.

(b) Another female head of colossal size, very similar in forms and expression, with half-open mouth, a highly-arched upper lip, and the same treatment of the forehead.

(c) A barbarian head, probably a Gaul's, displaying the characteristic Pergamene rendering of this type in the high cheek-bones, the hair and eye-

${ }^{1}$ Imhoof-Blumer, Die Münzen der Dynastie von Pergamon, Taf. 3, No. 19. 
brows ; but there is more realism of detail in this than (for instance) in the head of the Dying Gaul of the Capitoline.

Before beginning the review of the monumental evidence that proves the diffusion of Pergamene style throughout other localities, there are some literary notices that are valuable to collect.

Among the arts cultivated with the greatest success in the later Greek and the Greco-Roman period was that of mosaic; and it is probable that Rome was to some extent indebted to Pergamon for the introduction and expansion of this art. 'Celeberrimus fuit in hoc genere Sosus qui Pergami stravit quem vocant asaroton oecon' $;^{1}$ it is likely that he belonged to the earlier Attalid period, and it is possible that he was one of those who wrought the mosaics for the magnificent ship of Hiero II. of Syracuse (about 232 B.c.), which is one of the earliest recorded and certain instances of mosaic-work used for private luxury. ${ }^{2}$ Now it is shortly after the date at which the Pergamenian kingdom was ceded to Rome (B.c. 133) that this art became popular in the latter city; and that this is more than a mere coincidence seems indicated by the name that is commonly applied in later literature to the mosaic-pavement-asarotum and asarotici lapilli-a general term, derived from the Pergamene work. The theory could be better established if one could discover in Roman mosaic sure traces of the Pergamene style; and the attempt would be adventurous, as no mosaic has been found on the excavated site or in the vicinity of Pergamon, and it would be hazardous to seek in so different an art for the same style that appears in the sculpture; but a few clues of connection may be gathered, chiefly from the representation in mosaic of Alexander's battle.

In his Campanische Wandmalere $i^{3}$ Helbig has thrown out the suggestion that this work is derived from an original-probably a painting-that belongs to the same epoch and tendency as the Attalid historic sculptures. We may note that the same principle is observed here as there in the rendering of the barbaric type, and some of the same features reappear, and the real type is given without excessive naturalism. Now it cannot be said that any and every achievement in historic art in the Hellenistic era immediately falls to the credit of the Pergamene school, for Cyrene or Alexandria may claim to have done work of the same kind and power in regard to the African nationalities. But it is much more probable that the type of the Persian race was originally a theme of Asia Minor art rather than of Greco-Libyan or Greco-Egyptian. And the mosaic in question is not without evidence in support of this. There is a certain resemblance-that must not however be too much insisted upon-between the figure of the Persian who is transfixed by the spear of Alexander, and that of the young giant who is falling before Athene on the altar-frieze. His face and the faces of some of the other Persians show something of that character and that expression in eyes and

\footnotetext{
1 Pliny, N.H. 36, 184.

2 The art of mosaic had been employed perhaps as early as the fifth century for the decora-

H.S.-VOL. XI.
}

tion of temple-pavements; vide Letronne, Lettres d'un Antiquaire, pp. 313-315.

3 P. 44. 
forehead that mark the gigantesque type; and the reflection of the prostrate Persian's countenance in his own shield recalls to our mind a similar trait in Sosus' mosaic, the reflection of the bird's head in the water. I am aware that these indications are of rather slight force; but they combine with more general considerations of probability to connect the mosaic with the historic work of the later epoch rather than with the picture of the Egyptian Helena to which ${ }^{1}$ Overbeck would refer it. The violent dramatic spirit, the highlywrought pathos, the masterful characterization of the Persian race, are features in the work that are difficult to reconcile with the belief that the original was painted by a woman in Egypt soon after the middle of the fourth century B.C.

The popularity of the work of Sosus is proved also by the existing imitations; the birds drinking from the cup on the Herculaneum mosaic are a reproduction of part of his subject, but it throws no light on any special character of style. As has been already said, it is scarcely fruitful to try to find any main stream of Pergamene influence in Roman mosaic-work; but here and there in certain themes a certain affinity may be observed.

The literary record concerning Pergamene art, that is next in importance to the record of the Attalid dedications at Athens, is a series of epigrams describing the representations in relief on the pillars of the temple that was raised at Cyzicus by Attalus II. and Eumenes II. in honour of their mother Apollonis. According to the transcriber of the epigrams they were actually

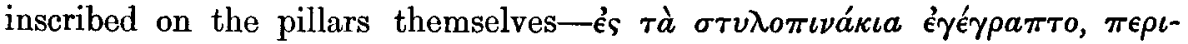

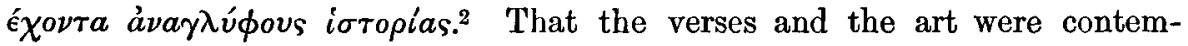
poraneous in their origin cannot be believed, as the irregularities of the metre point to a very late period; perhaps their inscription is only imaginary, and they are the work of a late Byzantine. But there can be no doubt that they describe actual monuments, the decoration of the temple-pillars at Cyzicusand record some of the productions of the artists who worked for Attalus and Eumenes. Many of the subjects can be illustrated, and some have a special interest for Pergamene legend, and may very probably be the work of the sculptors who carved the smaller Pergamene frieze. The first ${ }^{3}$ in the series is a representation of Bacchus leading Semele to Olympos with Hermes preceding, and an escort of Satyrs and Sileni with torches. The text is too vague to tell us much about the composition, but we may conjecture a youthful Dionysos standing in the chariot by the side of Semele in the centre of the scene.

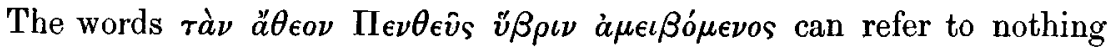
that was there in the scene, unless we suppose a combination of two separate myths on the same slab; and the evidence of other monuments cannot help us towards any reconstruction of it, for with the exception of one broken vase we have no representation of the ascent of Semele. The chief interest of the

\footnotetext{
1 Pompcii, p. 425.

2 The epigrams were first noticed by Visconti, Iscrizioni Greche Triopee, p. 102 : for :textual criticism vide Jacob's Excreitationes Criticae,
}

vol. ii. p. 139 ; they have scarcely received any arehacological criticism.

3 Vide Anth. Pal. iii. 1. 
record is that it gives us another example of the figure of Dionysos as a theme of Pergamene sculpture; and I have already noted with what peculiar expression and forms the type of the god was handled by the men of this school, to whom chiefly, we may believe, the later modifications of the type are due. But it is doubtful whether there is any Greco-Roman sculpture dealing with this subject in which we can definitely trace the effect of their work. The head of Bacchus in Leyden, published in the Mon. dell' Inst., ii. 41, and described by Furtwängler ${ }^{1}$ as being 'd'une expression puissante et animée, d'un grand élan et empreinte de ce pathétique un peu rude qui caractérise les sculptures de Pergame,' appeared to me, on personal observation of it, scarcely to have the value thus ascribed to it, and to show little affinity in its forms to Pergamene style.

The choice of this subject for the decoration of the Cyzicene temple need not have been suggested by the local worship of Dionysos at Pergamon, but by the desire to illustrate the affection between son and mother-the idea expressed in nearly all these reliefs. ${ }^{2}$

The second representation is that which stands in the closest connection with the local legend: the recognition of Telephos by his mother Auge, the incident that is recorded by Hyginus, and perhaps was found in the Mvoo of Sophocles. The Cyzicene relief has a particular interest, because its subject is closely connected with that of one of the smaller frieze-slabs that have been brought from Pergamon, on which in spite of its mutilation, we can discover the form of Telephos ${ }^{3}$ and the serpent that miraculously intervenes between the son and the mother to prevent the intended matricide. On a vase of the later archaic period we see Telephos fully armed and pursuing Auge who is hastily retreating (Arch. Zeit. 1853, Taf. 60). But neither of these representations can give us an exact clue to that on the temple of Apollonis; for both these are dramatic and violent, but the words of the epigrammatist evidently describe a peaceful situation, the moment of the discovery, and the purpose of Telephos to lead his mother back to his native land; and such a scene accords well with the whole of this series of mythic subjects. But it is very rarely ${ }^{4}$ found among surviving monuments, and it may take rank by the side of the smaller frieze as illustration of the original work done by the Attalid sculptors in the field of Pergamene myths.

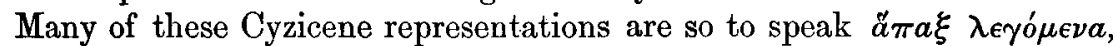
far-fetched themes of which existing works supply us with no illustration, and which are chosen merely as mythic or historic records of filial piety. It is only necessary here to mention those that have some discoverable relation with known monuments, and some importance for the history of Pergamene sculpture. Great interest attaches to the sixth and the fourteenth representation, the former being the slaughter of Python, the latter the death of

1 Collect. Sabouroff, vi. 23.

2 But the presence of the Sileni in the scene may be an allusion to the Dionysiac society that

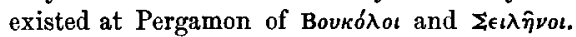
Vide inscription, vol. vii. p. 40 of Hernes.
3 Vide sketch in Jahrb. d. deut. Inst. 1887, p. 245, fig. C.

4 The meaning of the relief in Brocklesby Hall (Michaelis, Ancient Marbles), 'Telephos and Auge,' is very doubtful. 
Tityos at the hands of Apollo and Artemis. From the heading and the text of each epigram we can partially reconstruct the scenes. In the first Leto is

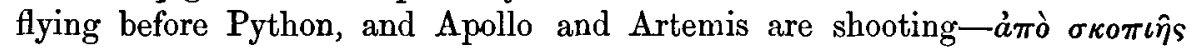
$\Delta \epsilon \lambda \phi \hat{\omega} \nu$. We must suppose that the rocky terrain was indicated, and from

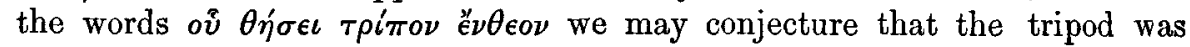
actually seen near the god, as it is in the representations of Apollo Pythoctonos on the coins of Rhegium. What is unusual in the Cyzicene rendering of the myth is the presence of Artemis in the first place; for apart from this instance she is not, as far as I am aware, found in this scene, except in those rare and different vase-representations which show Leto fleeing from Python and holding the twin children in her arms; secondly, the presence of Leto herself interpreting the myth as an illustration of filial piety.

Apollo is avenging Leto for Python's pursuit of her at the time of his birth; only thus will this scene express the idea of the whole series. But this is the rarer and probably not the original view of the myth, and in support of it we can only quote the legend of Hyginus, the vase-representation mentioned above, and the Homeric hymn to Apollo as it appears in the fanciful reconstruction of $O$. Gruppe. ${ }^{1}$

The fourteenth epigram describes a very similar subject, and the figures of Artemis, Apollo, and Leto appear again. The form of the dying Tityos may have been lying at the feet of Apollo, and thus the group would have closely resembled that in the Pergamene frieze of Apollo and the fallen giant of human shape, as in a former paper it has been noticed how the Pergamene Apollo resembles the slayer of Tityos as he appears on a red-figured vase. ${ }^{2}$ While in the earlier vase-representations, for instance on an archaic Corinthian vase in the Louvre, Tityos though usually wounded is often still erect and retreating, the sculptor of the Cyzicene slab has followed what was probably a prevalent mode of treating this theme. We gather from the epigrammatist's words that the giant was streaming with blood from his wounds, and we have here an indication of that love of sensational realism which is seen so frequently in works of this school.

From the Pergamene and Cyzicene monuments, then, we have evidence that the type of Apollo was familiar in Pergamene sculpture, as we know also that he enjoyed special worship both at Cyzicus and Pergamon. ${ }^{3}$ We may also suppose, as the sculptors were dealing with closely cognate themes, namely, the slaying of the giants, of Pytho, and of Tityos, and as the action of the god is on the whole the same in each, that the pose and form of Apollo was very similar in all these representations. And we may enlarge the group of works connected with the Belvidere statue by including in it these representations on the Cyzicene temple.

The seventh epigram describing the representation of the fate of Dirce is of great importance, as it is the only sure proof we have that Pergamene

\footnotetext{
1 Die Griechischen Kulte und Mythen, p. 530.

2 Hellenic Jonurnal, 1885, p. 127.
}

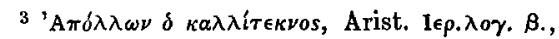
Dind. 469 ; Hekataeus, Frag. Müller, 202. 
sculpture dealt with this theme. For the Farnese group by itself is insufficient evidence, its authenticity being so corrupted by excessive restoration that, though we may find a general resemblance to Pergamene manner and spirit in its picturesque character, in its dramatic violence, and in its expression of the pathos of merely physical suffering, yet we cannot find in it the surer formal marks of affinity. And the inscriptions found at Pergamon, at first supposed to show that one of the sculptors of the Farnese group was employed for the decoration of the Pergamene altar, are now admitted by Dr. Conze to be doubtful. But the epigram proves that the main motives of the Cyzicene representation were the same as those of the monument in Naples.

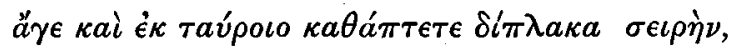

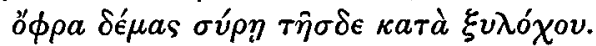

Both brothers are engaged in tying Dirce by a double cord to the bull, and the body is to be dragged along a bushy ground-a picturesque trait found in the Farnese group and similar to some in the reliefs of the smaller Pergamene altar-frieze. And it seems probable that Antiope also was present and that Dirce was making appeal to her; at least this is grammatically the most ratural interpretation of the words

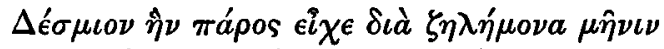

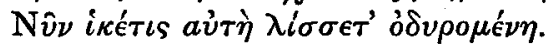

Whether the Farnese group or the Cyzicene relief was the earlier is hard to say, but the epigram justifies us in bringing the former into near relation to Pergamene sculpture. It may be that the myth was first handled by painting, as it seems a theme more appropriate to that art; but we have no proof of any representation earlier than the Pergamene, and there is nothing to hinder us supposing that it was in this school that the subject first received artistic treatment. We find the same scene on a relief from Volterra and on two Pompeian frescoes: ${ }^{1}$ on the former and on one of the frescoes we find something of the Pergamene style in the expression and rendering of the face.

The eleventh epigram describes the myth of Polydectes and Perseus, who is turning him to stone with the Gorgon's head. The verse implies that the sculpture was able to express the petrefaction of the limbs: how this was possible for an art that had obtained complete mastery in the handling of the surface may be gathered from that frieze-slab of the grent altar, on which a youthful giant with stiffened limbs is sinking down before the aegis of Zeus.

The evidence of the epigram supports the supposition that among the existing representations of Medusa we may find traces of the Pergamene hand. Certainly in the range of its expression and some of its forms, the Ludovisi head shows affinity with the work of this school, as has 
been pointed out by Trendelenburg, ${ }^{1}$ who compares it with the head of the youthful giant in the first slab of the Pergamene frieze $(A)$; but here it is the still living energy of rage and hatred that is expressed in the contorted features, while in the Medusa the bitterness of pain and hate is shadowed indeed in the lips and drawn eyelids, but there is an approach in the features to frozen insensibility, and the expression is not so violent but profounder. In both works, however, we see the strong expression of a pathos that is more physical than mental, and this is a marked though perhaps not a 'peculiar' property of Pergamenian sculpture. As regards the forms of the Ludovisi head, the long wavy hair, the large eye-sockets, the arched lip recall the well-known characteristics of this style, but the face has not the usual contour nor the usual lines and depressions.

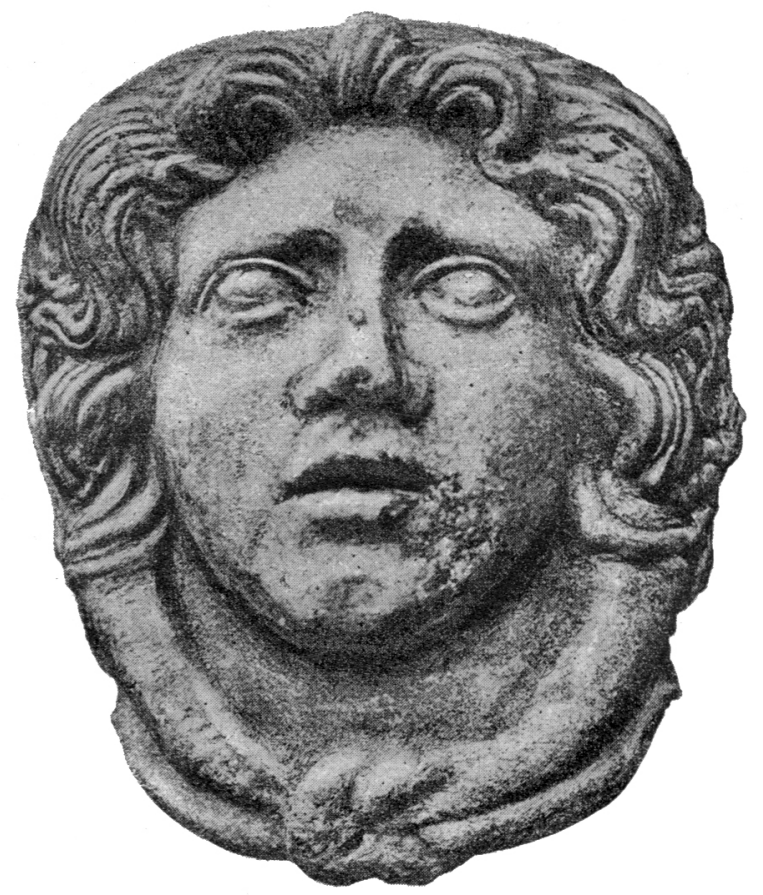

FIG. 2.

There is another head of Medusa, a terra-cotta mask from Tarentum (Fig. 2), published in the Gazette Archéologique, 1883, Pl. 3, which the writer there classes among works of this school. The head is in private possession; but so far as one may judge from the reproduction, the view about its origin or affinity is correct. The wrinkled forehead, the breadth of face, the distance between the eyes, the form of the mouth and of the arched upper lip, vividly remind us of some of the younger giants' countenances. Again, the Medusa 
head from Stabiae shows the same spirit of workmanship, and some of the forms are the same. ${ }^{1}$

But it would be rash to conclude with certainty from the above evidence that this type of Medusa-with its romantic expression, with the strained pathos of its forms-was the achievement of the Pergamene school. It may be that an older generation discovered a mode of expression for the agony of death, and that this became a traditional mode for rendering the dying passion of a Laocoon, a Medusa, or a youthful giant. Only there are no monuments that prove this type to be older than the earlier Pergamene era; and there was no other school in the Alexandrine period that possessed such mental aptitude, so to speak, for the fullest representation of physical horror. At least the works that have been compared help us to conceive how the Medusa appeared on the Cyzicene relief.

The historic incident represented in the relief described in Epigram 17the sons carrying their parents on their backs to save them from an eruption of Etna-is not without interest, in that the story recalls the myth of Aeneas and Anchises; and this representation may be compared with the GrecoRoman representation of Anchises on the shoulders of Aeneas. A late and much defaced statue in Cologne of a warrior armed with helmet, sword, and cuirass, and bearing on his left arm a man who holds some oblong object on his lap may represent an Aeneas with his father. The latter's head is missing, but the warrior's face shows something of the Pergamenian type in the deepset eyes and the lines about the brow and lips.

The last epigram of this series has this unique interest, that it gives us the earliest instance of the rendering of a Roman myth by Greek art. The scene on the slab was the deliverance of their mother by the twins Romulus and Remus; and we might almost believe from the words of the epigram that the suckling of the twins by the wolf was represented on the same relief by that sort of 'contaminatio' of incidents which sometimes appears in the later sarcophagi. That Pergamene sculpture was the first to treat of Roman legend is not not only a proof of the pelitical friendship of the two states, but also assists the belief in the strong influence of Pergamene art in the Roman period.

And it may be more than a mere coincidence that the earliest known monument that illustrates certain scenes from the Virgilian epic, the Roman Columbarium, published in Mon. del Inst. X., Tav. 60, shows many points of connection with Pergamene work. Some of these have been noticed by Professor Robert in the Jahrbuch des Deutschen Instituts, ${ }^{2}$ who compares the building of Alba Longa, as represented on the Columbarium, with the building of the city on one of the slabs of the Telephos frieze. We may notice also the resemblance between the recumbent figure of the river-god, in the scene on the Roman work showing the exposure of the twins, with the deity in the Pergamene representation of the deliverance of Prometheus, the pose and drapery being the same in both; also between the female figure- 
probably a nymph-seated on a rock and a person of like form and in like pose on the Telephos frieze. We find also certain motives that were favoured by the sculptors of Pergamon in their representations of combat appearing in the battle of the Trojans and Rutulians on the Columbarium; such as the fallen warrior with his head on his arms and his hair streaming to the earth, and the warrior planting his foot on the body of another prostrate combatant and dragging his spear from the wound.

These are the most important contributions that this series of epigrams offers to our list of genuine Pergamene works. A detailed analysis of the text might further reveal the occurrence on the Cyzicene reliefs of certain 'common-places' of Pergamene art; for instance, in the third scene, where Phoenix

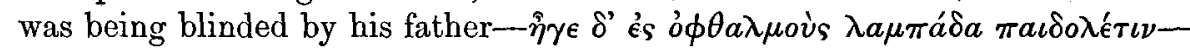
the blazing torch thrust into the face recalls more than one passage in the Pergamene gigantomachy. To show the action of fire on flesh implies a facility-acquired late by Greek sculpture-to produce picturesque effects; and I do not remember to have seen this motive in any Greek monument of plastic art earlier than the Pergamene period.

Among the literary records of works at Pergamon we need only notice for the present purpose those which we may believe to refer to works that were actually produced by the sculptors or painters who worked in this style. It is not always easy to say whether the record has this value, or merely describes something that had been brought to Pergamon by the zeal of the

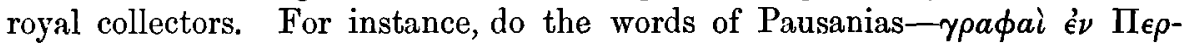

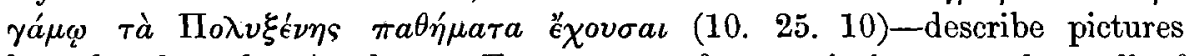
brought there by Attalos or Eumenes, or fresco-paintings on the wall of some public building there? The latter is perhaps more probable, as he is speaking of a connected series of paintings. In this case we have a record of Pergamenian art, and obviously the subject is of that pathetic nature that would attract an artist of this school; but as far as I know there is no existing monument of the Polyxena legend that at all betrays the influence of this style.

Among the sculptors employed by Attalus II. was Epigonos, whose name is preserved by a Pergamene inscription, and who no doubt is the same as the sculptor mentioned by Pliny, 34. 88: 'Epigonos praecessit in tubicine et matri interfectae infante miserabiliter blandienti.' It has been suggested with some probability that the 'tubicen' is a Gallic warrior with the curved trumpet; and the second work also may have represented a slain Gallic or barbarian woman with her mourning child : both subjects belonging then to the sphere of historic sculpture, and the latter offering opportunity for the expression of the highest pathos. The connection of the Ludovisi head called Medusa with Pergamene art can hardly be doubted; and if, as is now often believed, it is no Medusa head at all, ${ }^{1}$ we might interpret it as the head of a barbarian woman sinking to the ground in death. And it might be

1 Friederichs-Wolters's Baustcine. But Professor Brunn, in a recent paper, has ably and convincingly defended the old view. 
a copy from the Greek period of the "mater interfecta" of Epigonos. A very similar subject was found in a painting of Aristides, the contemporary of Alexander ('oppido capto ad matris morientis ex volnere mammam adrepens,' Pliny, 35. 98), which may have inspired the work of Epigonos. There was at least one painting of Aristides in Pergamon. Being a great master in the expression of pathos, for whose works Attalus I. appears to have been very zealous, he may have exercised on Pergamene painting the same sort of influence as was exercised by Scopas on its sculpture.

We have abundant ancient testimony to prove that many cities of northern and central Asia Minor were subject to the Pergamene dynasty or exposed to its influence, ${ }^{1}$ and in many cases it can also be proved that the artistic style of Pergamon was diffused where the dynasty acquired political power. An instance of the wide radiation of this influence is the giant's head from Trebizond, published by this Journal in 1886. The connection of Pergamon with Cyzicus is shown not only by the epigrams in the Anthology, but also by the records concerning Stratonicus and Phyromachus; the former a native of Cyzicus and one of the plures artifices (qui) fecere Attali et Eumenis adversus Gallos proelia, ${ }^{2}$ the latter being one of the same group of sculptors, and famous for his Asclepius that stood in the Nikephorion of Eumenes II. and was carried off by Prusias of Bithynia, and for his Priapus that he wrought for Cyzicus. ${ }^{3}$ We perhaps obtain some impression of this statue from the later coins of Lampsacus with the representation of Priapus leaning on a thyrsos and offering a libation over an altar-flame. We might believe then that among monuments found on the site of Cyzicus we could discover Pergamenian tendencies of style; but our stock of these is very scanty: and I can only mention the coin-type of certain Cyzicene staters, on which appears a figure of a lion-hearted man with wings resembling closely the giant on the Pergamene frieze with whom a young god is wrestling; and a bas-relief from Cyzicus, now in Constantinople, representing a battle of the Greeks and Gauls, one of the Gallic heads closely resembling in type the chieftain's head in the centre of the front of the sarcophagus of Amendola, which latter work undoubtedly shows the Pergamene influence. ${ }^{4}$

Itaea, the port of Pergamon, and Attalia founded by Attalus II., 5 probably contained monuments that belonged to this class. I have already mentioned the torso in the British Museum from the first of these places, and on one of the coins of Itaea we see a native myth in the representation of Auge being rescued by fishermen from her chest-a very pictorial subject that might be derived from a Pergamene painting. ${ }^{6}$ A coin-type of Attalia is a running Artemis with two torches-possibly a type of Pergamene religious sculpture.

At Tralles and at Parion there were monuments of Pergamene work : at

I Vide especially Livy, xxxviii. ch. 39 .

2 Pliny, xxxiii. 154, and xxxiv. 84.

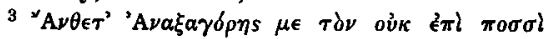

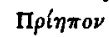

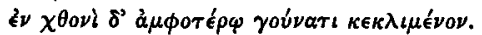

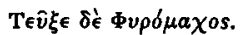

Anth. ii. 120, 9 : Planud. iv. 239.

4 Vide Reinach, Revue Archéol. 1889, p. 320.

5 Strabo, 667.

6 Mittheil. d. deutseh. Inst. 1885, p. 21. 
the former a palace of Attalus II., built and adorned by artists in his employ; at the latter a large altar, erected by Hermocreon, a sculptor who worked for Eumenes II., and Parion seems to have been generally favoured by the dynasty. We hear of their political connection with Smyrna and Phokaea, ${ }^{1}$ but we have no monuments, so far as I am aware, that illustrate this. The head of Bacchus, reported to have come from Smyrna, ${ }^{2}$ is indeed ascribed by Furtwängler to the Pergamene class, being, as he writes, 'd'une expression puissante et animée, d'un grand élan et empreinte de ce pathétique un peu rude qui caractérise les sculptures de Pergame;' but on observation of the original I was unable to detect any close affinity with this style. The expression is excited but superficial, and neither the expression nor forms of the face nor treatment of the hair serve to remind us at all vividly of any Pergamene head.

Of the close connection between Pergamon and Ephesus there is much ancient evidence, ${ }^{3}$ and that a certain community of style prevailed in the work of the two cities is probable enough. It is true that we can gather little that is positive from any monument of sculpture; for the Borghese warrior in the Louvre who appears to be defending himself from the attack of some horseman, and the statue at Athens found in Delos which M. Reinach compares with it, ${ }^{4}$ do not show the distinct peculiarities of this school, though there is a certain affinity to Pergamene work in the mode of representing the action; it is a mere conjecture therefore to say that they are derived from the Athenian group of Attalus' dedication, and that they are statues of Greeks defending themselves from Amazons. But in the terra-cottas from Ephesus we occasionally find traces of the style of this school ; for instance, in the small Ephesian terra-cotta in Berlin, a youthful satyr's hear in the same pose and of the same expression as the head of the 'dying Alexander ;' and in another small terra-cotta from the same site, also in the Berlin Antiquarium (marked No. $7597, b$ ), a female head with ivy-leaves, perhaps Ariadne, in features and expression something like the well-known Pergamene female-head.

We have two monuments of the Greco-Roman period, one from Aphrodisias in Caria and one from Telmessos in Lycia, ${ }^{5}$ that have a direct or indirect connection with the Pergamene ; both are relief-representations of the Gigantomachy, and in the figure of Zeus and some of the giants' forms on the former, and in the pose of Zeus and Apollo on the latter relief, we are reminded of some of the sculpture of the large altar. ${ }^{6}$ It is unfortunate that we do not know the 'provenance' of any of that large group of statues in Naples, Venice, the Louvre, and elsewhere, representing barbarians, Amazons, and giants, and derived in some way from Pergamene originals. If $\mathbf{M}$.

\footnotetext{
3 Polybius, v. 77.

2 Published in the Mon. ael. Inst. ii. 41, and by Furtwängler in Collection Sabouroff, vi. 23.

3 Livy, xxxviii. 39, and Strabo, 641.

${ }^{4}$ Bull. de Corresp. Hell. 1889 (Janvier), Plate XI.
}

5 Telmessos is among the places mentioned by Livy as ceded to Eumenes II. by the Romans for his help in the war against Antiochus. Livy, xxxviii. 39.

6 Vide Overbeck, Atlas zur Kunst Mythologie, Bd. I. Taf. v. ; cf. Mon. del. Inst. III. xv. 
Reinach's theory that they are copies from Asia Minor of works at Pergamon or Athens could be proved, they would afford the most striking instance of the wide diffusion of Pergamene influence throughout Asia Minor. We might suppose also that it spread to some of the adjacent islands, but at present archaeology has offered no proof of this. Naturally the island which stood in the closest relation to the Attalid capital as a centre of art was Rhodes, but the question how this relation should be expressed may be reserved, as it raises the whole question concerning the Laocoon.

In tracing this influence throughout later art it might be well to follow first the clue afforded by certain themes which Pergamene art had made especially its own. That which was most strictly proper to this locality was the myth of Telephos. Originating in Arcadia, it received there no expression ${ }^{1}$ in art except at the hands of Scopas, who carved on the temple of Tegea that part of the myth which possessed the greatest Hellenic interest, the battle between the Greeks and Mysians. But elsewhere in Greece there were representations of certain details of the legend. The healing of Telephos, owing doubtless to the influence of the Attic drama, had become a theme of fourth century art, as Professor Robert has pointed out, ${ }^{2}$ and we may conclude from Pliny's ${ }^{3}$ statement that this subject was treated by other schools of Greek painting besides the Pergamene. We cannot therefore refer off-hand to some work of this school as the archetype of each of the later representations of the various parts of the Telephos legend, but only when the style of such monuments points in this direction.

This is especially the case with those monuments of the Greco-Roman period which represent the discovery of Telephos, who is sucking the roe while Heracles is looking on. ${ }^{4}$ The most striking of these is the Pompeian picture $;^{5}$ the figure of Heracles agrees with that in the similar representation of the smaller Pergamene frieze; and the expression of the face is proper to this school; and certain details also suggest that this is a copy of a Pergamene original-the fringe on the drapery of the goddess, who probably personifies the mountain Parthenion, and the type of the lion who stands behind Heracles.

We may compare with the Pompeian picture the same representation showing marks of the same style on the terracotta relief belonging to the Berlin Antiquarium, in which the arrangement of some of the figures and the pose of Heracles, who is holding up his club before him and touching his

${ }^{1}$ In Tegea there was also a temple and a

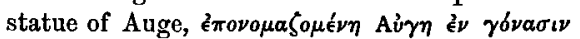
(Paus. viii. 48, 5) ; this probably has no reference to the myth of Telephos' birth, but the

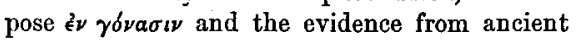
Spartan sculpture-a representation of a kneel. ing woman between two divinities of childbirth, published Mitth. d. deutsch. Instituts, 1885-suggest that the worship and the statue at Tegea refer to Eileithyia, and the name Pausanias gives us may be due to a popular mis- understanding.

${ }^{2}$ Bild und Lied, p. 35.

3 Pliny, xxxiv. 45.

4 I have suggested in Hell. Journ. 1886, that in all probability this group is an original invention of the Pergamene school; there is only negative evidence for this belief, and even this is not complete as long as we do not know the date of the representation of Telephos and the goat seen by Pansanias at Helicon : ix. 31, 2 .

5 Vide Zahn, iii. 
chin with his hand, are different, but which shows the type of features common to works of this class. In the representation on the Cameo of Commodus in the Berlin Museum, where the same scene appears, the attitude of Heracles is again somewhat different, as he stands with both hands held down in a less meditative posture.

A later moment of the same drama is marked by the representation in the Louvre of the infant Telephos in the arms of Heracles: a work that may be a good Roman copy of a Pergamene original. The face of the hero is of the same type here and in the Pompeian picture; and the bodily forms recall those of the Glyconian statue.

We can searcely doubt that this latter, the colossal Farnese Heracles, is a work wrought under the influence of the same style; but the view that it presents a type that was originally devised for the group of Heracles and Telephos can no longer be maintained. For in the earliest example of it-a fine tetradrachm, ${ }^{1}$ of Alexander, the hero stands alone: and in the wall relief found at Alyzia, ${ }^{2}$ of nearly the same age, the solitary figure of Heracles is seen in nearly the same attitude. We cannot describe this type as that of Heracles gazing on his son, or of Heracles with the apples of the Hesperides, for it is only in a very few of the later intances ${ }^{3}$ that the hand which is behind his back contains the fruit, but simply as one type of the resting Heracles. This then was borrowed for the theme of Telephos by the Pergamene school, who borrowed so much, and was modified so far that the right arm was brought across the chest; from what ancient work or from what older sculptor they derived it we cannot determine. For of the different reasons that have been brought forward for assigning it to Lysippus, none is of any scientific value; and the Farnese statue, in its exaggeration of the merely physical force, in its ' mountains of gross flesh,' in the realism of its details such as the treatment of the veins and eyelids, is very far from the style of Lysippus as we know it from record or from monument, but shows in the body at least a later development or degeneracy from the Pergamene style. The head is not distinctly Pergamene but its forms may be traced back to the latter part of the fourth century. ${ }^{4}$ In fact only one representation by this school of the Heracles countenance has been preserved, namely in the relief of Prometheus and the vulture at Berlin; and as the face of Heracles is here youthful, it does not show any very close affinity to the Farnese type.

In later representations of the giants we find, as we might expect to find, that the influence of Pergamene style has been considerable.

We must of course remember in this connection the dying giant at Naples, but for reasons above given it cannot be regarded as a striking achievement of

1 Numismatic Chronicle, 3, Ser. III. Taf. I. 5.

2 Heuzey, Mont Olympe et Acarnanie, Pl. XI.

${ }^{3}$ In nearly all the instances the hand with the apples is modern; a genuine example is the coin of Philippopolis struck in the reign of Caracalla (Müller-Wieseler, Denk. d. a. K. $\mathbf{I}$. No. 155). On the other hand nearly all the antique representations of Heracles with the apples are of quite different type; e.g. Clarac, Musée de Sculpt. P1. 787, 1969, 1971.

4 As Helbig (Annali dell' Instituto, 1868, p. 336) has shown by comparing it with the head of Heracles in the Museum of Bale, which he supposes to be of gond Greek period, but which seemed to me rather to be excellent work of the early Roman period. 
this school. Of far greater importance and in far nearer relation to this art is the head of the dying Alexander at Florence which I have before compared in detail with some of the heads of the frieze; and we may even say the same of the little fragment from Trebizond in the British Museum which was published in the Hellenic Journal, year 1886. A fragment in the Central Museum of Athens may be mentioned here because in my opinion it belongs to a representation in relief of a gigantomachy in a style closely resembling the Pergamene, though the marble is different from that found so abundantly on the site of Pergamon. It has been described and photographed in the Mittheilungen des deutschen Instituts, ${ }^{1}$ and my observation of the original confirmed the impression which the photograph gives, that it is a monument of the Greek period. It is a naked male torso with traces of a large curl of hair on the shoulder (Fig. 3).

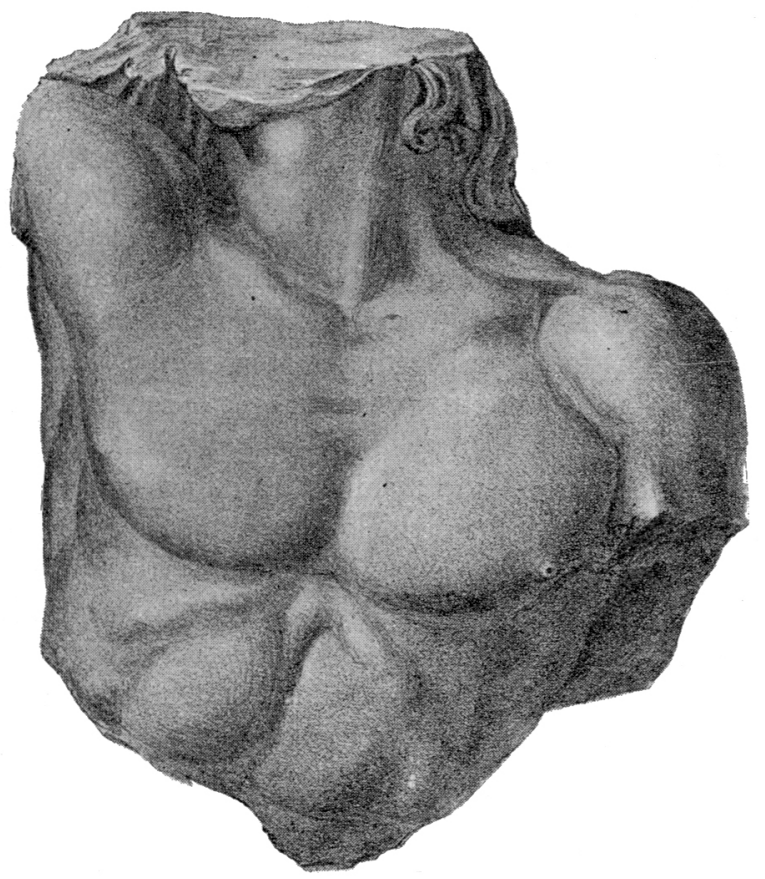

FIG. 3.

The pose is violent and the body distended as of one giving back from a blow and desperately defending himself, for the right arm is uplifted and he seems falling forward to the right; or we might imagine that the right arm was brought back over the head and we might interpret the whole posture by means of the very similar figure in the Pergamene frieze of the youthful giant overthrown by Athene. As the limbs are thus at full stretch we do not see that massing together of the muscles which is so noticeable in many figures of the larger Pergamene frieze, but the muscles are large and rendered with 
much softness, and these soft surfaces, the dramatic and pathetic posture, the rendering of the diaphragm and of the strained columnar throat, the hint of the flowing masses of hair, are reasons that speak strongly in favour of the above interpretation.

It is needless here to enumerate those later monuments of the Gigantomachy published in Overbeck's Atlas zur Kunst-Mythologie that show nearly or remotely the influence of Pergamene work; many of these have already been mentioned in these papers, and in some cases the illustrations in Overbeck are evidence sufficient. A very important monument of this class which has strangely remained hitherto without much notice is a statuette about 3 feet 6 inches in height belonging to the Museum of Carlsruhe ${ }^{1}$ (Fig. 4). The pose of the figure is not unlike that of the Athenian torso. It probably represents a numan-limbed giant who has fallen on his knees in the fight, while his antagonist-a divinity who must have been attacking him from his left -was dragging back his head until it touched his shoulder: both the giant's arms are missing, but the left must have been outstretched in the attempt to press back his antagonist, and the right was probably raised towards the giant's head. The marble seems to be Italian and the work to belong to the early Roman period. The motive is the very commonest in the wide range of the representations of this myth, often used but not invented by the Pergamene school. The torso and the face, much of which seems to have been polished by the action of water, show the imitation and the exaggeration of the Pergamene manner: the lips which are so notable a feature of the type in question are here half covered with the beard, but the mouth is wide open; the eye-sockets are very deep and seem to have been hollowed out by a borer; the centre of the forehead is corrugated; the wild hair is tossed about in thick clusters; the muscle-surfaces of the torso are large and swollen. The work is said to have been found in the year 1883 in the ruins of a Roman villa near another statue which belongs also to this style. The Carlsruhe fragment is all the more interesting-unless the interpretation here given is wrong-because it and the group in Wilton House of Heracles and the giant are the only instances as yet discovered of the treatment of this myth by free sculpture.

To the early Roman, perhaps the Republican, period belongs the fragment in Naples, published in the Archaeologische Zeitung by Lange, $1883 \mathrm{p}$. 82 , and no doubt correctly interpreted by him as the fragment of a giant who is serving as an architectural support. The figure is also partly dramatic, as the pose of the head and the expression of the features show that he is cowering beneath the thunderbolt. The Pergamene style appears unmistakably in the treatment of the hair, the eye, and the mouth. The giant's figure serving as an architectural support is found in early Greek and in late Roman art: among such monuments may be mentioned one-so far as I know un-

1 Photographed and briefly noticed by Lanciani in the Bull. della Commiss. Archacol. Comunale di Roma, xii. year 1884, p. 213-214, who suggests that it represents a Prometheus bound; he compares other representations of Prometheus, e.g. Millin, Gall. Afyth., P1. XCIII., but the Carlsruhe fragment proves that the legs were posed differently. 


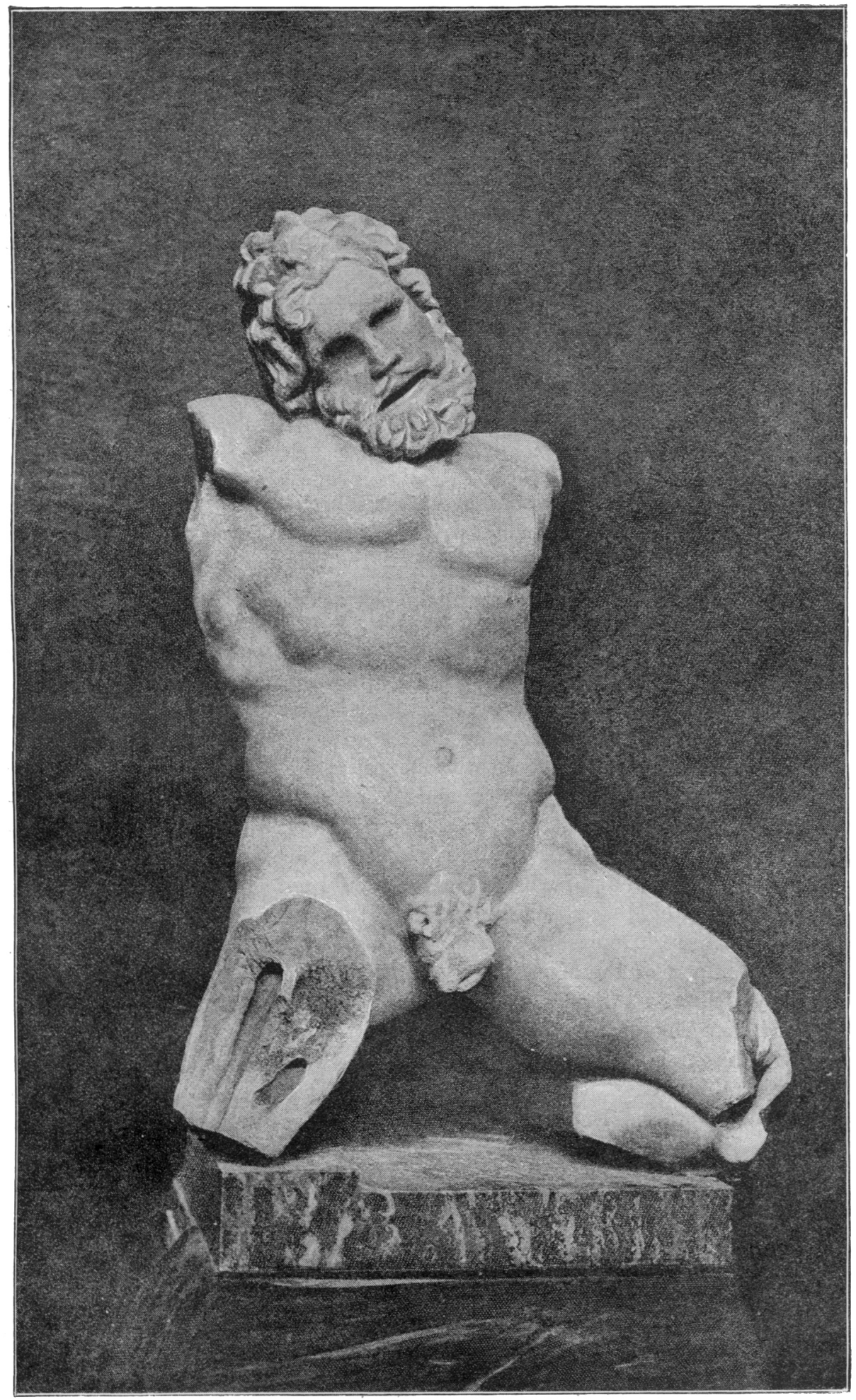

Fig. 4 
published-in the museum at Trier, an architectural fragment with several figures of giants, of little importance except as showing in the features and treatment of the muscles the distant influence of the work of the Attalid group of sculptors.

Other later works dealing with the same theme may be mentioned to show the long survival of the earlier style. The Igel monument, erected by a noble Roman family of Trier, still stands on the left bank of the Moselle some six miles above the city, scarcely impaired by the changes of seventeen centuries. It preserves many figures of the old mythology and religion, and on the north side, up the face of one of the Corinthian columns, is a figure in relief that is derived from the artistic tradition of the Gigantomachy, a young giant halfsinking to the ground with his arm over his head in an attitude that recalls the figure in the corner of the relief on the staircase of the great Pergamene altar.

Perhaps the most interesting monument of sculpture that has survived on German soil from the late Roman period is the mysterious monument found at Merten near Metz and now preserved in the Museum of the latter city. It has been published and described in the Revue Archeologique, ${ }^{1}$ but the evidence which could precisely fix the date and historical reference has yet to be discovered. It is mentioned here on account merely of the curious group which crowns the edifice, a cavalier in the cuirass of a Roman soldier striking down a half-human serpent-legged giant who holds a stone in his right hand while extending his left arm obliquely behind him. It is rough stonemason's work but not without spirit; the material is red sandstone; the face of the giant is very savage and shows an exaggeration of that traditional type of features that we are tracing. It is well known that the Gigantomachy like the battles of the Amazons was the symbol of the struggle between civilization and barbarism, and it would not surprise us to find in the neighbourhood of Metz a representation of the combat of the gods and the giants, or a historic representation of the contest between Roman and barbarian. But the sculptor of the Merten monument has confused the symbol with the thing symbolized : a Roman soldier striking down a giant is an unique and rather ludicrous motive.

So far as I am aware these are all the works existing in Europe that deal with this theme and preserve something of the manner of the Pergamene school of sculpture. But in cognate subjects, such as the combats of Bacchus with the Indians, we might expect to find reminiscences of this style : and we certainly seem to find them-so far as can be judged from a sketch-in the representation of a sarcophagus in the cathedral of Cortona. ${ }^{2}$ The interpretation. of the figures has been matter of difficulty, but probably the view of Klügmann ${ }^{3}$ is correct, that it is a scene of combat between Bacchus with his following and the Indians. But if it was not for the fact that the enemies of the god appear to be issuing or retreating through the gateway of a city, and

1 Vide the year $1879, \mathrm{Pl}$. II.

${ }^{2}$ Published in the Arch. Zeit. 1845, Pl.
$\mathrm{XXX}$.

${ }^{3}$ Arch. Zeit. 1869, p. 31 . 
that one of them wears 'anaxyrides' we might naturally suppose that the youthful warriors with their wild hair, their excited mobile features, were not Indians but giants, as is also suggested by their fighting with stones. It is not only their features but their action and forms that remind us of Pergamene work. The young Indian who throws himself in the way of Dionysos' chariot and threatens the Centaurs who are drawing it might be compared with the opponent of Artemis on the frieze of the great altar. We have here monumental evidence of the analogy that is sometimes expressed in literature between the Indian campaign of Bacchus and the Gigantomachy.

So far the traces of the Pergamene style have been noted in monuments that are known to have had some connection with Pergamon or that dealt with subjects that had been appropriated by its school. I shall afterwards try to show that the same style has touched the representation of subjects that had not necessarily this local connection : and that from its wide application we can ascribe to it a deep influence upon the later days of classic art.

L. R. Farnell. 